CORRECTION

\title{
Publisher Correction: Genomic prediction for hastening and improving efficiency of forward selection in conifer polycross mating designs: an example from white spruce
}

Patrick R. N. Lenz (D), Simon Nadeau (D), Aïda Azaiez, Sébastien Gérardi, Marie Deslauriers, Martin Perron, Nathalie Isabel, Jean Beaulieu and Jean Bousquet

(c) The Author(s) 2022

Heredity (2022) 128:196; https://doi.org/10.1038/s41437-022-00501-9

Correction to: Heredity https://doi.org/10.1038/s41437-019-0290-3, published online 22 January 2020

Due to a processing error, the column headers of table 3 are displaced.

The original article has been corrected.

\begin{abstract}
cc) (i) Open Access This article is licensed under a Creative Commons Attribution 4.0 International License, which permits use, sharing, adaptation, distribution and reproduction in any medium or format, as long as you give appropriate credit to the original author(s) and the source, provide a link to the Creative Commons license, and indicate if changes were made. The images or other third party material in this article are included in the article's Creative Commons license, unless indicated otherwise in a credit line to the material. If material is not included in the article's Creative Commons license and your intended use is not permitted by statutory regulation or exceeds the permitted use, you will need to obtain permission directly from the copyright holder. To view a copy of this license, visit http://creativecommons. org/licenses/by/4.0/.
\end{abstract}

(c) The Author(s) 2022 